Journal Universitas Muhammadiyah Gresik Engineering, Social Science, and Health International Conference (UMGESHIC)

UMGCINMATIC : $1^{\text {st }}$ Rethinking Education during Covid-19 Era: Challange and Innovation

\title{
THE EFFECT OF RETURN ON ASSET, RETURN ON EQUITY, LEVERAGE, AND EARNING PER SHARE ON COMPANY VALUE
}

\author{
Author \\ Aulia Mei Lutfia', Umaimah ${ }^{2}$ \\ Universitas Muhammadiyah Gresik ${ }^{1,2}$ \\ auliamltf@gmail.com¹,umaimahumg@gmail.com²
}

\begin{abstract}
This study aims to determine how big the influence of return on assets, return on equity, leverage, earnings per share on firm value in LQ45 index companies in 2017-2020. This study uses quantitative methods and uses secondary data as a data sources. The sampling technique used purposive sampling technique and obtained data as many as 104 samples of companies. The data analysis technique used is multiple regression analysis. The results showed that return on assets variable had a significant effect on firm value. Return on equity and leverage as proxied by debt to equity ratio (DER), both have an insignificant effect on firm value. Earnings per share variable has a significant effect on firm value.
\end{abstract}

Keywords: Return On Assets, Return On Equity, Leverage, Earning Per Share, Firm Values.

\section{INTRODUCTION}

Development investation in Indonesia the more increase by significant, based on data from the Indonesia Stock Exchange, the use of the IDX index of Rp. 2.72 trillion in funds under management at the end of 2015 to Rp. 15.88 trillion in end year 2020, or grow an average of $42 \%$ per year in the last 5 years.

Based on phenomenon could cause competition business which very strict between companies. In face competition economy in era globalization, companies must have certain goals. One of the main goals company in period long that is Upgrade Mark company which tall. The value of the company is one of the things that becomes a benchmark for investors who want to relation to price shares of a company.

Price share reflect indicator existence success in manage company. Movement price share will move unidirectional, because stock price something company influenced by perception market to condition company moment this and performance which they hope in time future. Whereas uncertainty condition economy moment this make price share changed- change by not expected so that price share could risky down and result in the value of the company decreases. Maximizing Mark company could achieved when company pay attention to stakeholders, namely investors. The main goal of investors is to seek dividend income. Investors prefer to invest capital the stock on company which have performance which good in optimize value 
company. In condition Thus, every company required to be able to operate with a high enough level of efficiency so that still have advantages and competitiveness in an effort to generate profits clean as optimal as possible (Salempang et al., 2016) .

High company value is the desire of company owners, because a high value indicates the prosperity of shareholders who tall. A high firm value will make the market believe that performance and prospect company in time front very good. By because that Mark company reflects how the management performance of the company so that Mark company is wrong one reject measuring which must for considered in invest, Case the Becomes reason done study this.

\section{METHODS}

a. Research Sample This research uses a quantitative approach, namely the type of research which results in discoveries that can be obtained by using statistical procedures or other means of measurement. While the population in this study are LQ45 companies registered in Indonesia Indonesia Stock Exchange (IDX) 2017-2020 taken by purposive sampling, namely the sampling technique with consideration of certain criteria. The data collection technique used in this research is the method documentation, namely by collecting data from reports that have been processed by other parties so that researchers can obtain the information needed.

b. Operational Definition and Measurement of Variables

1) Dependent Variable

The dependent variable of this study is the proxy value of the company with PBV. Price to Book Value (PBV) describes how big the market value the book value of a company's shares. Firm value is measured by using the formula:

$$
\text { Company value }=\frac{\text { Market Price per Share }}{\text { BookValue per Share }}
$$

2) Independent Variable

This study uses several independent variables, namely Return On Assets (ROA), Return On Equity (ROE), Leverage (DER) and Earning Per Share (EPS). The explanation of the concept and operational variables is explained separately in next section.

a) Return On Assets $\left(\mathrm{X}_{1}\right)$

The first independent variable in this study is Return On Assets then symbolized X 1 . Profitability Proxied by Return On Assets (ROA) is the ratio between net profit after tax to the average total assets. Return On Assets is measured using the formula:

b) Return On Equity $\left(\mathrm{X}_{2}\right)$

$$
\text { Return On Asset }=\frac{\text { Net Profit After Tax }}{\text { Total Assets }}
$$

The second independent variable in this study is Return On Equity then 
symbolized $\mathrm{X} 2$. ROE is the ratio of net profit after tax to own capital is used to measure the rate of return on investment shareholders. The higher the ROE ratio indicates the company's performance better. Return On Equity is measured using the formula:

$$
\text { Return On Equity }=\frac{\text { Net Profit After Tax }}{\text { Total Equity }}
$$

c) Leverage $\left(\mathrm{X}_{3}\right)$

The third independent variable is Leverage, hereinafter symbolized by $\mathrm{X}_{3}$ . _ The ratio used in this study is the Debt to Equity Ratio (DER). which compares total debt with equity. Leverage measured by using the formula:

$$
\text { Leverage }=\frac{\text { Total Debt }}{\text { Total Equity }}
$$

d) Earning Per Share $\left(\mathrm{X}_{4}\right.$

The fourth independent variable is Earning Per Share, then symbolized by X 4 . EPS is earnings per share that can be seen in the income statement. Earnings Per Share is measured using the formula:

\section{Earning Per Share $=\frac{\text { Net Profit After Tax }}{\text { Number of Common Stock Outstanding }}$}

c. Data Analysis Techniques

This study uses multiple linear regression analysis techniques, to knowing the effect of Return On Assets (ROA), Return On Equity (ROE), Leverage (DER) and Earning Per Share (EPS) to firm value. As for the steps analysis of the data as follows:

a) Descriptive Statistical Test

Descriptive statistical analysis are statistical methods that work to describe the data that has been collected. A data can described by sum, mean, variance, standard deviation, minimum, maximum, skewness, kurtosis, and range (Ghozali, 2018:19) . In this study, statistics descriptive is used to find out about the description of the independent variable ( Return On Assets (ROA), Return On Equity (ROE), Leverage (DER) and Earnings Per Share (EPS)) through information on mean (average), standard deviation, maximum (highest value in data), and minimum (lowest value in data).

b) Classical Assumption Test

- Normality Test

Normality test aims to test whether in the regression model, the variable dependent, the independent variable is normally distributed or not. If there is normality, then the residuals will be distributed normally and independently (Ghozali, 2018:161) . To detect the normality of the data, it is done by using the test Kolmogorov-Smirnov (KS). If the result of the Kolmogorov-Smirnov test is the results of the significance value> 0.05 
then the data is normally distributed. However, if the value of significance $<0.05$ then the data is not normally distributed (Ghozali, 2018:30)

- Multicollinearity Test

The multicollinearity test aims to test whether the regression model is found there is a correlation between the independent variables (independent). Good regression model there should be no correlation between independent variables (Ghozali, 2018:107). Multicollinearity is seen from the tolerance value and the value of the variance inflation factor (VIF). Tolerance measures the variability of the selected independent variables that not explained by other independent variables. So a low tolerance value equals a high VIF value. The tolerance value limit is 0.1 and the VIF limit is 10. If the tolerance value is $<0.1$ or VIF $>10$ then it happens multicollinearity. On the other hand, if the tolerance value $>0.1$ or VIF $<$ 10 then there is no multicollinearity (Ghozali, 2018:107) .

- Autocorrelation Test

Autocorrelation test aims to test whether in the linear regression model there is correlation of confounding error in period $t$ with error in period $t$ 1 (previously). If there is a correlation, it is called an autocorrelation problem. Autocorrelation arises because successive observations over time are related each other (Ghozali, 2018:111) . To determine the presence of autocorrelation in a regression model is carried out through testing the value of the Durbin Watson test (DW). The criteria for testing autocorrelation using the method Durbin Watson is as follows:

If the number (DW $<\mathrm{DL}$ ) or (DW $>4-\mathrm{DL}$ ) means that it indicates the null hypothesis (H0) is rejected, so there is an autocorrelation.

If the number (DU < DW < $4-\mathrm{DU}$ ) means that it indicates the null hypothesis $(\mathrm{H} 0)$ accepted, so there is no autocorrelation.

If the numbers (DL DW DU) or (4 - DU) and (4 - DL) mean signify that cannot come to a conclusion.

- Heteroscedasticity Test

Heteroscedasticity test aims to test whether the regression model occurs the inequality of variance from the residual of one observation to another observation. If the variance from the residual of one observation to another observation remains, then it is called homoscedasticity and if different it is called heteroscedasticity. The regression results are whether there is homoscedasticity or there is no heteroscedasticity (Ghozali, 2018:137) . The heteroscedasticity test in this study was carried out by using the glejser test. If the significance value is between the independent variables with absolute residual more than 0.05 then there is no heteroscedasticity (Ghozali, 2018:142) 
c) Multiple Linear Regression Test

Hypothesis testing is done by statistical analysis of multiple linear regression for relate one dependent variable to several independent variables. In this study, regression analysis was carried out to determine whether there was the effect of Return On Assets (ROA), Return On Equity (ROE), Leverage (DER) and Earning Per Share (EPS) on the value of the company. The regression equation are as follows :

$$
Y=+\beta_{1} X_{1}+\beta_{2} X_{2}+\beta_{3} X_{3}+\beta_{4} X_{4}+e
$$

Description:

$\begin{array}{ll}\mathrm{Y} & =\text { Firm Value } \\ \alpha & =\text { Alpha } \\ \boldsymbol{\beta}_{1,2,3,4} & =\text { Regression coefficient of independent variables } \\ \mathrm{X}_{1} & =\text { Return On Assets } \\ \mathrm{X}_{2} & =\text { Return On Equity } \\ \mathrm{X}_{3} & =\text { Leverage } \\ \mathrm{X}_{4} & =\text { Earning Per Share } \\ \mathrm{e} & =\text { Strandart Error }\end{array}$

d) Hypothesis Test

- Simultaneous Test (F)

Simultaneous test is a useful test to see the effect of independent variables to the dependent variable. With this test, it can be seen whether accounting conservatism, Earnings management and firm size affect earnings quality. Taking decisions are made based on a comparison of the value of $\mathrm{F}$ count with $\mathrm{F}$ table. On In this study, the value of $\mathrm{F}$ count will be compared with $\mathrm{F}$ table at the level of significance $(\alpha)=5 \%$. If $\mathrm{F}$ count $<\mathrm{F}$ table, then $\mathrm{H} 0$ is accepted. And if F count $>\mathrm{F}$ table, then $\mathrm{H} 0$ is rejected or $\mathrm{H} 1$ is accepted.

- Partial Test (T)

Partial test is a test used to show how significant the effect is independent variable to the dependent variable. Tests are carried out using significance level of $0.05(\alpha=5 \%)$. Acceptance or rejection of the hypothesis is done by the following criteria:

If the significant value $>0.05$ then the hypothesis is rejected (regression coefficient is not significant). This means that partially the independent

variable does not have a significant effect on the dependent variable.

If the significant value 0.05 then the hypothesis is accepted (significant regression coefficient). This means that partially the independent variable has a significant influence on the dependent variable.

e) Coefficient of Determination Test

The coefficient of determination can be seen in the Adjusted $R$ Square value 
which shows how much large independent variables can explain the independent variables. The magnitude of the coefficient determination is 0 to one. The higher the Adjusted $R$ Square value, the means the better the regression model used because it indicates that the ability of the independent variable explains the dependent variable is also getting bigger, as well as if the the opposite happens.

\section{RESULT AND DISCUSSION}

\section{a. Descriptive Statistical Analysis Results}

Based on the results of descriptive statistical analysis, then in Table 4.1 will be shown The characteristics of the sample used in the study include the number of samples (n), the value of minimum, maximum value, sample mean (mean ) and standard deviation for each variable.

Descriptive Statistics

\begin{tabular}{|l|r|r|r|r|r|}
\hline & N & Minimum & Maximum & mean & Std. Deviation \\
\hline ROA & 97 &,- 06 &, 24 &, 0670 & 0.05890 \\
ROE & 97 &,- 18 &, 33 &, 1302 & 0.08006 \\
DER & 97 &, 18 & 16.08 & 2.2199 & 2.80866 \\
EPS & 97 & -308.47 & 5654.99 & 578,4541 & 962.85815 \\
PBV & 97 &, 41 & 6.77 & 2.1218 & 1.39353 \\
Valid N (listwise) & 97 & & & & \\
\hline
\end{tabular}

Table 4.1 Descriptive Statistical Test Results

Source: SPSS Output

Based on the results that have been obtained from the SPSS output shown in table 4.1 above, each variable has a total observation data of 97 data, it can be concluded that:

1) Variable $\mathrm{X} 1$ that is Return On Assets proxied by ROA has the maximum value is 0.2447 and the minimum value is -0.0572 with the average value owned is 0.066970 with a standard deviation of 0.0588981 . The mean value ( mean ) is greater than the standard deviation i.e. $0.066970>0.0588981$ which means that the distribution of Return On Assets is good.

2) Variable $\mathrm{X} 2$, namely Return On Equity proxied by ROE has the maximum value is 0.3295 and the minimum value is -0.1797 with the average value owned is 0.130167 with a standard deviation value of 0.800583 . The average value ( mean ) is smaller than the standard deviation of $0.130167<0.80583$ which means that the distribution of Return On Equity values is not good.

3) X3 variable, namely Leverage proxied by DER has a value of a maximum of 16.0786 and a minimum value of 0.1754 with a value of the average owned is 2.219896 with a standard deviation of 2.8086636 . The mean value ( mean ) is smaller than the standard deviation i.e. $2.219896<2.8086636$, which means that the distribution of the leverage value is not good. 
4) The $\mathrm{X} 4$ variable, namely Earning Per Share, which is proxied by EPS has the maximum value is 5654.9929 and the minimum value is -308.4676 with an average value of 578.454094 at the standard value deviation of 962.8581506 . The average value ( mean ) is smaller than the standard the deviation is $578.454094<$ 962.8581506 which means that the distribution of the EPS value not good.

5) Variable Y, namely the value of the company proxied by PBV has the maximum value is 6.7708 and the minimum value is 0.4069 with a value of the average owned is 2.121755 at the standard deviation value obtained is 1.3935280 . The average value ( mean ) is greater than the standard the deviation is $2.121755>$ 1.3935280 which means that the distribution of the value of Good company.

b. Classical Assumption Test Results

1) Normality Test Results

Normality test aims to test whether the data is normally distributed or not. To test whether the data is normally distributed or not, it can be done with the One. Test Kolmogrov-Smirnov sample. Here are the results of the normality test:

ANOVA ${ }^{a}$

\begin{tabular}{|rl|r|r|r|r|l|}
\hline \multicolumn{1}{|l|}{ Model } & \multicolumn{1}{|c|}{$\begin{array}{c}\text { Sum of } \\
\text { Squares }\end{array}$} & df & \multicolumn{1}{c|}{$\begin{array}{c}\text { Mean } \\
\text { Square }\end{array}$} & F & Sig. \\
\hline \multirow{2}{*}{1} & Regression & 58.045 & 4 & 14.511 & 17,356 &, $000^{\mathrm{b}}$ \\
& Residual & 76.083 & 91 &, 836 & & \\
& Total & 134,128 & 95 & & & \\
\hline
\end{tabular}

a. Dependent Variable: PBV

b. Predictors: (Constant), EPS, DER, ROE, ROA

Table 4.6 Simultaneous Test Results (Test F)

Source: SPSS Output

In table 4.6 above, it shows that the calculated $F$ value is 17.356 with a significance of 0.000 . The results of this simultaneous test can be known by means of a comparison between the calculated $\mathrm{F}$ value and the table $\mathrm{F}$ value at a significant level ( ) $5 \%$. The $\mathrm{F}$ table value is obtained from the formula $\mathrm{df} 1=\mathrm{K}-1$ where $\mathrm{K}$ is the number of variables. Then determine df 2 with the NK formula, where $\mathrm{N}$ is the number of research data, $\mathrm{N}$ in this study amounted to 97 data, after there was a data transformation, it was reduced by one to 96 . The results of these calculations obtained the results of df1 $(5-1=4)$ and df2 $(96-5=91)$ then the value of $F_{\text {table }}$ is 2,47 . From the results above, it is obtained that $F$ arithmetic $>F$ table is $17.356>2.47$ and also the level of significance below 5\% (0.05) then $\mathrm{H}$ 0 is rejected or $\mathrm{H}_{\mathrm{a}}$ is accepted. So it can be concluded that simultaneously Return On Assets $\left(\mathrm{X}_{1}\right)$, Return On Equity $\left(\mathrm{X}_{2}\right)$, Leverage $\left(\mathrm{X}_{3}\right)$ and Earnings Per Share $\left(\mathrm{X}_{4}\right)$ together have an effect on firm value $(\mathrm{Y})$.

2) Partial Test Results (T Test)

Partial test is carried out to test whether each independent variable has an 
effect significant to the dependent variable. To find out which variables have significant effect on the dependent variable, then a partial test was performed. Here are the results from partial hypothesis testing:

Coefficients ${ }^{\text {a }}$

\begin{tabular}{|c|c|c|c|c|c|c|c|}
\hline \multirow[t]{2}{*}{ Model } & \multicolumn{2}{|c|}{$\begin{array}{l}\text { Unstandardized } \\
\text { Coefficients }\end{array}$} & $\begin{array}{l}\text { Standardized } \\
\text { Coefficients }\end{array}$ & \multirow[t]{2}{*}{$\mathrm{t}$} & \multirow[t]{2}{*}{ Sig. } & \multicolumn{2}{|c|}{$\begin{array}{l}\text { Collinearity } \\
\text { Statistics }\end{array}$} \\
\hline & B & $\begin{array}{c}\text { Std. } \\
\text { Error }\end{array}$ & Beta & & & Tolerance & VIF \\
\hline (Constant) & ,412 &, 147 & & 2,810 & ,006 & & \\
\hline ROA & 14,300 & 4,951 & ,547 & 2,888 & ,005 & , 174 & 5,761 \\
\hline ROE & 2,538 & 2,923 & ,153 & ,868 & ,388 & ,200 & 4,990 \\
\hline DER & 0.040 & ,065 & 0.059 & 621 & ,536 & 680 & 1,471 \\
\hline EPS & ,000 & 000, &,- 163 & 2,014 & 0.047 & ,956 & 1.046 \\
\hline
\end{tabular}

a. Dependent Variable: PBV

Source: SPSS Output

Table 4.7 Partial Test Results (T Test)

Based on table 4.7, it can be seen that the $\mathrm{T}$ count value obtained from each variable. To determine the conclusions from the results of the $t$ test, first determine the $t$ table used. The value of ttable is obtained from NK, where $\mathrm{N}$ is the number of samples and $\mathrm{K}$ is the number of dependent and independent variables. So that $\mathrm{df}=\mathrm{NK}=96-5=91$, then the table is 1.986 with a significance of 5\%. Then it can be concluded that:

- The significant value of the Return On Assets variable is 0.005 where this amount is less than 0.05 . The tcount is 2.888 and the ttable value is known to be 1.986 . From the results obtained, tcount > ttable $(2.888>1.986)$, so $\mathrm{H} 1$ is accepted and $\mathrm{H} 0$ is rejected.

- The significant value of the Return On Equity variable shows 0.388 where this number is greater than 0.05 . For tcount is 0.868 and the table value is known to be 1.986 . From the results obtained, tcount < ttable, namely $(0.868$ $<1.986$ ), which means $\mathrm{H} 2$ is rejected and $\mathrm{H} 0$ is accepted.

- The significant value of the Leverage variable is 0.536 , where this number is greater than 0.05 . The tcount is 0.621 and the ttable value is known to be 1.986. From the results obtained, tcount $<$ ttable, namely $(0.621<1.986)$, which means $\mathrm{H} 3$ is rejected and $\mathrm{H} 0$ is accepted.

- The significant value of the Earning Per Share variable is 0.047 where this number is smaller than 0.05 . The tcount is $-2,014$ and the ttable value is known to be 1,986 . From the results obtained, tcount < table, namely $(-2,014$ $<1,986$ ), which means $\mathrm{H} 4$ is accepted and $\mathrm{H} 0$ is rejected. 
c. Coefficient of Determination Test Results (R2)

The coefficient of determination test is used to measure how big the independent variable is can explain the dependent variable. The intensity of influence can be seen from the value of Adjusted $R$ squares. If the higher the value of Adjusted $R$ Square, it means the better the model regression used because it indicates that the ability of the independent variable explain the dependent variable is also getting bigger. The following are the results of the coefficient test determination in this study:

\begin{tabular}{|l|r|r|r|r|r|}
\hline $\begin{array}{l}\text { Mode } \\
1\end{array}$ & R & R Square & $\begin{array}{c}\text { Adjusted R } \\
\text { Square }\end{array}$ & $\begin{array}{l}\text { Std. Error of } \\
\text { the Estimate }\end{array}$ & $\begin{array}{l}\text { Durbin- } \\
\text { Watson }\end{array}$ \\
\hline 1 &, $658^{\mathrm{a}}$ &, 433 &, 408 &, 9143736 & 1,882 \\
\hline
\end{tabular}

a. Predictors: (Constant), EPS, DER, ROE, ROA

b. Dependent Variable: PBV

Table 4.8 Coefficient of Determination Test Results Source: SPSS output

From table 4.8, it can be seen that the Adjusted $R$ Square value is 0.408 . These results prove that the Return On Assets $\left(\mathrm{X}_{1}\right)$, Return On Equity $\left(\mathrm{X}_{2}\right)$, Leverage $\left(\mathrm{X}_{3}\right)$ and Earning Per Share $\left(\mathrm{X}_{4}\right)$ variables are able to explain the Firm Value (Y) variable of $40,8 \%$. Meanwhile, the remaining $59.2 \%$ is another variable that can affect the value of the company outside of this study.

d. Interpretation of Results

1) Effect of Return on Assets on Firm Value

Based on the hypothesis test above, the results of this study are the same as those of (Pioh, Tommy, \& Sepang, 2018), (Chandra et al., 2020) and (Rahayu \& Asandimitra, 2014) which prove that Return on Assets own significant influence on firm value. The greater the value of return on assets, the higher the value of a company, which means companies that have large profits in a high rate of return on company assets so that they are able to show good performance prospects. The results of this study support the signaling theory which shows that high profitability can attract investors to invest in the company because high profitability will increase the return on profits invested by investors. High profitability will give a signal that the company can develop well in the future. This condition certainly gets a positive market sentiment so that they are interested in investing by buying shares of the company in question. Therefore, the higher the company's ability to generate profits, the greater the return expected by investors and the impact on the value of the company also increases.

2) Effect of Return on Equity on Firm Value

Based on the hypothesis test above, the results of this study are the same as research (Apriada \& Suardikha, 2016) which proves that return on equity does 
not have a significant effect on firm value, which means that investing not only sees a high rate of return but investors also look at environmental conditions. investation. If the rate of return is high, but the investment conditions are not good, then investors will consider an investment. The results of this study are not in accordance with the signal theory basis which shows that high profitability can attract investors to invest in the company because high profitability will increase the return on profits invested by investors. High profitability will give a signal that the company can develop well in the future. Therefore, Return On Equity has no effect on firm value.

3) Effect of Leverage on Company Value

Based on the hypothesis test above, the results of this study are the same as research (Nurminda, Isynuwardhana, \& Nurbaiti, 2017) which proves that leverage does not have a significant effect on firm value, which means that an increase in debt will reduce the company's income because it causes a burden. The use of greater debt will increase the risk of the company being unable to pay its debts, so that the risk of bankruptcy is higher. Investors will be more careful in companies that have a high debt ratio. The results of this study are not in accordance with the signal theory basis which shows that the high leverage value, but the company is still able to pay its leverage obligations, the company is considered good in using leverage, so that it is able to pay its obligations. It can be concluded that Leverage has less effect on investment decisions so that it does not affect firm value.

4) Effect of Earning Per Share on Company Value

Based on the hypothesis test above, the results of this study are the same as those of (Pioh et al., 2018) and (Chandra et al., 2020) which state that earnings per share have significant influence on firm value. The greater the value of EPS, the value of the company will be better. The results of this study are in accordance with the basis of signal theory which shows that the management will show a signal through financial reports to investors about the company's prospects. High Earning Per Share shows that the level of efficiency and effectiveness of the company's sales management is good. Therefore, a high Earning Per Share can give a good signal to investors, so that the positive response shown by investors will increase the stock price so that the value of the company increases as well.

\section{CONCLUSIONS AND SUGGESTIONS}

a. Conclusions

Based on the description from the beginning to the end of the discussion, the following conclusions are obtained:

1) Return on Assets has a significant effect on firm value.

2) Return On Equity has no significant effect on firm value. 
3) Leverage has no significant effect on firm value.

4) Earning Per Share has a significant effect on firm value

b. Suggestions

1) The next researcher expands the research sample such as researching manufacturing companies, property and real estate and so on.

2) Updating variables that are thought to be able to affect the value of the company or can add moderating variables or control variables such as company size, sales growth, and so on.

\section{REFERENCES}

Apriada, K., \& Suardikha, MS (2016). Effect of Share Ownership Structure, Capital Structure and Profitability on Firm Value. E-Journal of Economics and Business, Udayana University, 201-218.

Brigham, EF, \& Houston, JF (2010). Fundamentals of Financial Management. In 1 (11th Ed.). Jakarta: Salemba Empat.

Chandra, A., Putri, AP, Angela, L., Puspita, H., Auryn, F., \& Jingga, FC (2020). The Effect of Earnings Per Share, Dividend Policy, Cash Flow, Leverage And Return On Assets On Company Value In Property And Real Estate Companies Listed On The Indonesia Stock Exchange. Journal of Accounting Research , 15 (1), 1-13.

Darmadji, \& Fakhruddin. (2012). Capital Market in Indonesia (Third). Jakarta: Salemba Empat.

Fahmi, I. (2014). Corporate Finance and Capital Market Management (1st Ed.). Bogor: Media Discourse Partners.

Ghozali, I. (2018). Multivariate Analyst Application With IBM Spss 25 Program . Semarang: Diponegoro University Publishing Agency.

Hamidy, RR, Wiksuana, IGB, \& Artini, LGS (2015). Effect of Capital Structure on Firm Value With Profitability as an Intervening Variable in Property and Real Estate Companies on the Indonesia Stock Exchange. E-Journal of Economics and Business, Udayana University , 4 (10), 665-682.

Hanafi, MM, \& Halim, A. (2004). Financial Management . Jakarta: Pt.Bpfe.

Hani, S. (2015). Financial Statement Analysis Techniques . Medan: Umsu Press.

Harmoni. (2009). Balanced Scorecard-Based Financial Management (Theory, Cases, and Business Research Approaches) . Jakarta: Earth Literacy.

Mabruroh, V., Riswan, \& Lestari, S. (2015). The Effect of Price Earning Ratio, Leverage, Dividend Payout Ratio, Profitability, and Cash Holdings on Firm Value in Non-Financial Companies Listed in the Lq45 Index. Tegal Polytechnic E-Journal , 4 (1), 82-90.

Nurminda, A., Isynuwardhana, D., \& Nurbaiti, A. (2017). The Influence of Profitability, Leverage, and Firm Size on Firm Value (Study of Manufacturing 
and Consumption Goods Sub-Sector Companies Listed on the Indonesia Stock Exchange for the Period 2012-2015). E-Proceedings Of Management , 4 (1), 542-549.

Pioh, HT, Tommy, P., \& Sepang, JL (2018). The Influence of Debt To Equity Ratio, Earning Per Share And Return On Assets To The Value Of The Food And Beverages Sub Sector In The Indonesia Stock Exchange. Emba Journal: Journal of Economic Research, Management, Business And Accounting , 6 (4), 3018-3027.

Rahayu, FD, \& Asandimitra, N. (2014). The Influence of Firm Size, Leverage, Profitability, Dividend Policy And Cash Holding On Firm Value In The Manufacturing Sector. Journal of Management Science (Jim), 2 (2), 548-561. Salempang, LE, Sondakh, JJ, Pusung, RJ, Accounting, J., Economics, F., \& Salempang, LE (2016). Effect of Return on Assets, Debt To Equity and Sales Growth on Company Value in the Real Estate and Property Sector Listed on the Stock Exchange in 2013-2014. Scientific Journal of Efficiency , 16 (3), 813-824.

Sudana, IM (2015). Corporate Financial Management (2nd Ed.). Jakarta: Erlangga. Suwardika, INA, \& Mustanda, IK (2017). The Effect of Leverage, Company Size, Company Growth, And Profitability on Company Value in Property Companies. E-Journal of Unud Management , 6 (3), 1248-1277. 